\title{
Peduncular hallucinations in brainstem encephalitis drawn by a patient
}

Figure The patient's sketches of his visual hallucinations

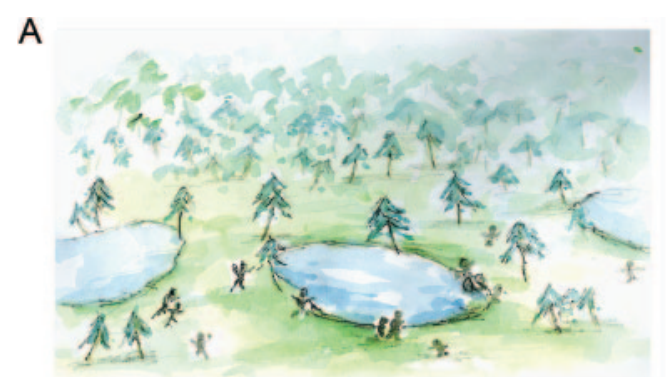

B

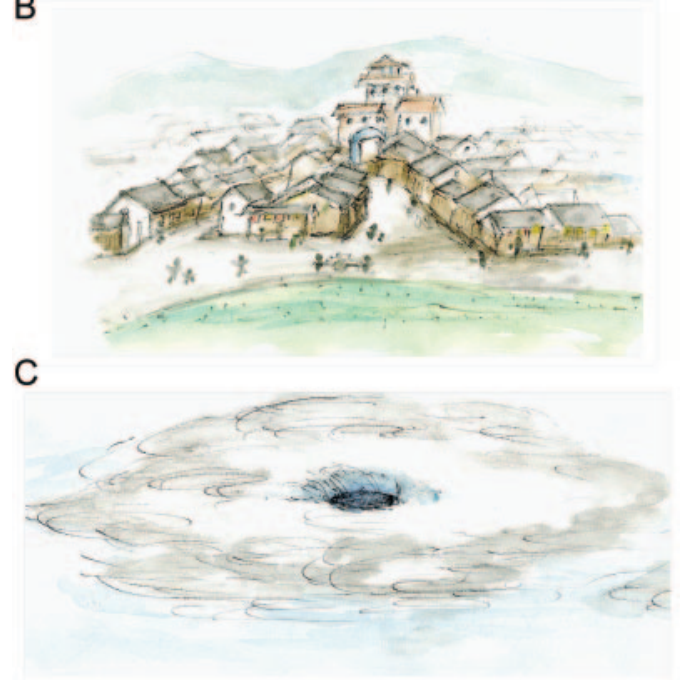

Sketched after recovery: (A) children and adults playing around ponds or trees in early summer; (B) people walking or working in the old Japanese castle city; (C) the core of a typhoon.

A 74-year-old man presented with acute cerebellar ataxia, ophthalmoplegia, left facial dysesthesia and weakness, dysarthria, dysphasia, and hyperreflexia. Episodic evening hallucinations occurred, triggered by eye closing, and lasted minutes; they were unaccompanied by paranoia, delusions, or REM sleep behavior disorder. We diagnosed brainstem encephalitis, apparently immune-mediated because IV immunoglobulin and corticosteroid therapy improved his symptoms. MRI excluded infection, tumor, or infarction of brainstem; the CSF was normal except for protein of $59 \mathrm{mg} / \mathrm{dL}$. After recovery, he sketched vivid, colorful pictures (figure) of the hallucinations.

Peduncular hallucinations are vivid, with colorful people, animals, or scenes, triggered by eye closure without disturbance of consciousness or psychotic symptoms, ${ }^{1}$ as in this case.

Yuichi Hayashi, MD, PhD, Nobuaki Yoshikura, MD, Akio Kimura, MD, PhD, Takashi Inuzuka, MD, PhD, Gifu, Japan Author contributions: Dr. Hayashi: diagnosis, patient care, drafting/revising manuscript. Dr. Yoshikura: patient care. Drs Kimura and Inuzuka: review of manuscript, patient care.

The authors report no disclosures relevant to the manuscript. Go to Neurology.org for full disclosures.

Correspondence \& reprint requests to Dr. Hayashi: hayashiy@gifu-u.ac.jp

1. Manford M, Andermann F. Complex visual hallucinations: clinical and neurobiological insights. Brain 1998;121:1819-1840. 


\section{Neurology}

\section{Peduncular hallucinations in brainstem encephalitis drawn by a patient Yuichi Hayashi, Nobuaki Yoshikura, Akio Kimura, et al.}

Neurology 2012;79;1625

DOI 10.1212/WNL.0b013e31826e2673

\section{This information is current as of October 8, 2012}

\section{Updated Information \&} Services

References

Subspecialty Collections

Permissions \& Licensing

Reprints including high resolution figures, can be found at: http://n.neurology.org/content/79/15/1625.full

This article cites 1 articles, 0 of which you can access for free at: http://n.neurology.org/content/79/15/1625.full\#ref-list-1

This article, along with others on similar topics, appears in the following collection(s):

All Clinical Neurology

http://n.neurology.org/cgi/collection/all_clinical_neurology Hallucinations

http://n.neurology.org/cgi/collection/hallucinations

Information about reproducing this article in parts (figures,tables) or in its entirety can be found online at:

http://www.neurology.org/about/about_the_journal\#permissions

Information about ordering reprints can be found online:

http://n.neurology.org/subscribers/advertise

Neurology ${ }^{\circledR}$ is the official journal of the American Academy of Neurology. Published continuously since 1951, it is now a weekly with 48 issues per year. Copyright Copyright $@ 2012$ by AAN Enterprises, Inc.. All rights reserved. Print ISSN: 0028-3878. Online ISSN: 1526-632X.

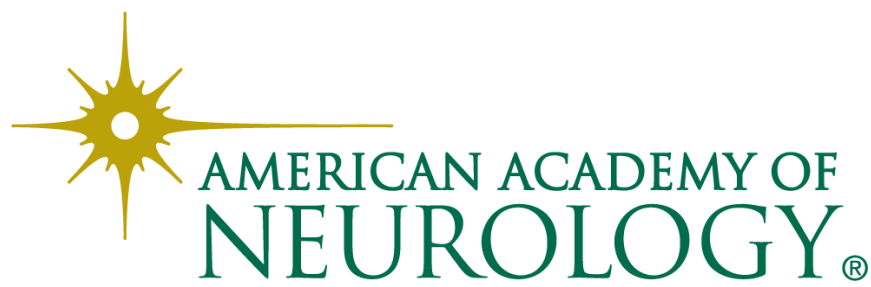

